\title{
Influence of Feeding Frequency on Growth performance and Body Indices of Goldfish (Carrassius auratus)
}

Muhammad Hafeez-ur-Rehman ${ }^{1}$, Khalid Javed Iqbal' ${ }^{2 *}$, Farzana Abbas ${ }^{1}$, Mirza Muhammad Haroon Mushtaq ${ }^{3}$, Fayyaz Rasool ${ }^{1}$ and Shakeela Parveen $^{1}$

${ }^{1}$ Department of Fisheries and Aquaculture, University of Veterinary and Animals Sciences, Lahore-Pakistan

${ }^{2}$ Department of Life Sciences, The Islamia University of Bahawalpur, Pakistan

${ }^{3}$ AgroVisions, Faisalabad, 38800, Pakistan

\begin{abstract}
A total of forty goldfish (Carrassius auratus) with an average weight of $20 \mathrm{~g}$ per fish were stocked in individual glass aquaria having $50-\mathrm{L}$ water holding capacity. There were 4 experimental feeding regimens $A, B, C$, and $D$ having once twice, thrice and four times per day, respectively. All the groups received Nova Aquarium Fish Food @ $2 \%$ bodyweight which was equally spaced in treatment groups. The body weight, body and caudal lengths, and girth were recorded at the start of the experiment. The trial continued for 8 weeks. Group B yielded the maximum weight gain whereas group $D$ yielded lowest weight $(P<0.05)$. Feed Conversion Ratio $(F C R)$ was better in Feed $A$ and depreciated with increasing frequency $(P<0.05)$. Caudal fin showed significant correlation with weight $(+$ $0.548 ; P<0.001)$ and length $(-0.792 ; P<0.0001)$. A positive correlation of dissolved oxygen $(D O ; P<0.001)$ and salinity $(P<0.0001)$ showed with temperature. Salinity showed positive significant correlation with temperature $(P<0.05)$. Consequently, feeding frequency twice per day is better for maximum body weight gain however better feed efficiency can be obtained at feed frequency once per day. However goldfish require genetic improvement for its rearing at commercial scale.
\end{abstract}

Keywords: Feeding frequency; Growth performance; Body measurements; Goldfish

\section{Introduction}

Ornamental fish culture is an important primary industry [1]. Ornamental fishes are often referred as alive jewels due to their beautiful colors, their body shape and natural behavior. They are very gentle, generally tiny, charming colors and could be easily accommodated in confined spaces. Modern ornamental fish culture and breeding operations have been intensified both vertically and horizontally, necessitating a continuous supply of nutritionally balanced, costeffective feed [2].

The goldfish (Carrassius auratus) belongs to the family Cyprinidae and is the most popular variety of ornamental fish. It was one of the earliest fish to be domesticated, and is one of the most commonly kept aquarium fish $[3,4]$. Like other fishes its growth and reproduction is influenced by numerous factors. Feed quality, quantity, composition and ingredient size, and feeding frequency are among the most important [5-7]. Though frequent feeding improves fish growth $[8,9]$ increasing feeding frequency beyond a particular level may lead to feed wastage and increase production costs [10]. Identification of the optimal feeding frequency helps to reduce feed wastage and maximize growth and reproduction.

Many authors studied the effect of feeding frequency on feed intake and growth in edible fishes [10-13]. Wang et al. [14] found that increased feeding frequency decreased inter-individual size variation among treatments. However, Zhou et al. [15] did not observe any effect of varying feeding frequency in juvenile gibel carp, Carrassius auratus gibelio, did some work on the influence of nutrition on growth and reproduction of ornamental fishes [16-18] but little attention has been paid to the impact of feeding frequency on growth and reproductive performance in ornamental fishes. Therefore, the present study was conducted to determine the effect of varying feeding frequency on growth and various body indices of goldfish, Carraius auratus.

\section{Materials and Methods}

The experiment was conducted at the Department of Fisheries and Aquaculture, University of Veterinary and Animals Sciences, Ravi Campus, Pattoki.

\section{Management and feeding}

A total of 40 Goldfish (Carassius auratus) was procured from Poonch Market, Choburgi Lahore-Pakistan weighs on average $20 \mathrm{~g}$ each. All the 40 individuals were divided equally into 20 tanks, with five replicates having 2 fish per replicate. Each tank has 10-L water holding capacity. There were 4 dietary groups, A, B, C and D. Group A served as a control and was fed once a day. Group B, C and D were fed twice, thrice and four times a day respectively. Time of feeding to different groups is followed as; Group A was offered feed at 0800, Group B was offered feed at 0800 and 1200, Group C was offered at 0800, 1200 and 1600, and Group D was offered feed at 0800, 1200, 1600 and 2000. A standard commercially available Nova Aquarium Fish Food was offered @ 2\% bodyweight ( $\mathrm{g} / \mathrm{g})$ split in equal parts as per requirement of each replicate. The amount of feed offered to the fish was close to the maximum daily ration consumed as per the local recommendations. The feeding trial lasted for 8 weeks. Faecal matter and unconsumed feed, if any, were siphoned before feeding. The unconsumed feed was filtered over a screen soon after the active feeding, dried and weighed to

*Corresponding author: Khalid Javed Iqbal, Department of Life Sciences, The Islamia University of Bahawalpur, Pakistan, Tel: 923326-022624; E-mail: khalidjavediqbal@gmail.com

Received February 06, 2015; Accepted March 17, 2015; Published April 30, 2015

Citation: Hafeez-ur-Rehman M, Iqbal KJ, Abbas F, Mushtaq MMH, Rasool F et al. (2015) Influence of Feeding Frequency on Growth performance and Body Indices of Goldfish (Carrassius auratus). J Aquac Res Development 6: 336. doi:10.4172/2155-9546.1000336

Copyright: () 2015 Hafeez-ur-Rehman M, et al. This is an open-access article distributed under the terms of the Creative Commons Attribution License, which permits unrestricted use, distribution, and reproduction in any medium, provided the original author and source are credited. 
Citation: Hafeez-ur-Rehman M, Iqbal KJ, Abbas F, Mushtaq MMH, Rasool F, et al. (2015) Influence of Feeding Frequency on Growth performance and Body Indices of Goldfish (Carrassius auratus). J Aquac Res Development 6: 336. doi:10.4172/2155-9546.1000336

measure the amount of feed consumed. Proximate composition of this feed has been given in Table 1 .

\section{Water analyses}

Water parameters were closely monitored and were kept within safe limits by regular flow management. The water parameters were evaluated in terms of $\mathrm{pH}$, temperature, dissolved oxygen (DO) and salinity. Water was analyzed for its $\mathrm{pH}$ by $\mathrm{pH}$ metre (LT-Lutron $\mathrm{pH}-207$ Taiwan), dissolved oxygen (DO) by DO metre (YSI 55 Incorporated, Yellow Springs, Ohio, 4387, USA). Moreover, temperature was recorded by the Combo meter (H M Digital, Inc. CA 90230). These observations were recorded twice (morning and noon) daily from different replicates.

\section{Growth and body indices}

Growth and morphometric parameters were carefully examined to predict daily feed ration. Each fish was individually weighed and all the other morphometric parameters were measured before the start of the trial and then in the lapse of every 2 weeks. The fish was removed from the tank individually and placed on laminated graph paper. Length from the mouth to the caudal peduncle and depth from the deepest point of the body to the base of the dorsal fin was measured ( $\mathrm{mm}$ ). Fish were then placed in a tarred beaker of tank water on an analytical balance for body weight measurements and then returned to their respective holding tank. The duration of study was 8 weeks.

\section{Statistical Analysis}

Data was subjected to One-way ANOVA Technique under completely randomized design. To determine significant differences $(\mathrm{P}<0.05)$ among the treatments means, Duncan's multiple range test was employed. Pearson correlation was applied to find out the correlation between the studied parameters. The level of significance was $<0.05$ or otherwise stated.

\section{Results}

Body weight and body indices of all the groups are shown in Table 2. Significantly higher initial body weight was observed in fish allocated to feed $\mathrm{B}$ followed by feed $\mathrm{A}, \mathrm{C}$ and $\mathrm{D}$, respectively $(\mathrm{P}<0.05)$. All the fish allocated were of equal length, means horizontal growth was not unlike among the various treatments $(P>0.05)$. Caudal length was found to be significantly higher in group $\mathrm{C}$, followed by $\mathrm{B}, \mathrm{D}$, and $\mathrm{A}(\mathrm{P}<0.05)$. More than $10 \%$ increase in caudal length has been observed in fish allocated to feed $\mathrm{C}$ as compared to feed A. The girth of fish allocated to group A and $\mathrm{B}$ was highest while the lowest response was observed in feed $\mathrm{C}$ and $\mathrm{D}(\mathrm{P}<0.05)$.

The observations of weight gain and feed conversion ratio (FCR) are shown in Table 3. The weight gain was improved in group B (68.5 g) while the better FCR was noticed in group A (1.28). Feed B showed 2.5 times improvement in weight gain as compared to feed $\mathrm{D}(68.5 \mathrm{vs.}$ $29.0 \mathrm{~g})$ while feed A responded almost 5 times better than feed D (1.28 vs. 9.66).

The correlation between weight, length, caudal fin, girth, $\mathrm{pH}$, temperature, DO and salinity is shown in Table 4 . The caudal fin of fish showed a highly positive correlation $(+0.548)$ with weight $(\mathrm{P}<0.01)$ and a negative correlation $(-0.792)$ with length $(\mathrm{P}<0.001)$ whereas the water DO showed a positive correlation $(+0.538)$ with water temperature $(\mathrm{P}<0.001)$. The salinity of water is positively correlated $(+0.729)$ with temperature $(\mathrm{P}<0.05)$.

\section{Discussion}

The positive correlation of the caudal fin with weight and length leads to the fact that the measurement of caudal fin could be a good criteria to estimate the weight of the fish. Increase in water temperature reduced the water DO and salinity so it also needed to maintain an optimum temperature for better dissolved oxygen and salinity level. There are some physicochemical viz. Temperature, Salinity, Conductivity, Dissolved Oxygen (DO), and $\mathrm{pH}$ which are considered to be important and critical water quality parameters in aquaculture $[19,20]$. Each water quality factor interacts with and influences other parameters, sometimes in complex ways [21]. Brian [22] and Ita et al. [23] noted that increased DO level is needed to support an increase in metabolic rates and reproduction. McElwee [24] described that temperature has an influence on salinity tolerance since they fluctuate together in nature and these fluctuations may positively or negatively influence growth and reproductive performance of cichlids. Watanabe et al. [25] observed that growth and survival in fish are not affected at different salinity levels when temperature exceeds $27^{\circ} \mathrm{C}$ but salinity has pronounced effect at temperatures below $25^{\circ} \mathrm{C}$

The initial observations in the present study did not affect further growth responses (on percent basis). In the present study the higher body weight was observed in fish fed to a frequency of two times per day. Similar results were observed by James and Sampath [26] in Red Swordtail (Xiphophorus helleri) which indicated that feeding twice a day resulted in the highest growth and reproductive success of this specie in a cultured system, when compared with 4 alternative feeding regimens

\begin{tabular}{|c|c|}
\hline \multicolumn{2}{|c|}{ Nutritional compositional $(\mathrm{g} / \mathrm{kg})$} \\
\hline Crude Protein & 170.0 \\
\hline Crude Fiber & 45.0 \\
\hline Crude Fat & 30.0 \\
\hline Moisture & 100.0 \\
\hline
\end{tabular}

Table 1: Proximate Composition of Nova Aquarium Fish Food.

\begin{tabular}{|l|c|c|c|c|}
\hline \multicolumn{1}{|c|}{ Parameters } & Feed-A & Feed-B $^{2}$ & Feed-C $^{3}$ & Feed-D $^{4}$ \\
\hline Body weight $(\mathrm{g})$ & $12.26 \pm 0.40^{\mathrm{ab}}$ & $12.45 \pm 0.36^{\mathrm{a}}$ & $11.01 \pm 0.54^{\mathrm{bc}}$ & $10.29 \pm 0.49^{\mathrm{c}}$ \\
\hline Body Length $(\mathrm{cm})$ & $7.45 \pm 0.09^{\mathrm{a}}$ & $7.57 \pm 0.09^{\mathrm{a}}$ & $7.37 \pm 0.16^{\mathrm{a}}$ & $7.27 \pm 0.10^{\mathrm{a}}$ \\
\hline Caudal length $(\mathrm{cm})$ & $2.71 \pm 0.07^{\mathrm{b}}$ & $2.88 \pm 0.06^{\mathrm{ba}}$ & $3.10 \pm 0.11^{\mathrm{a}}$ & $2.86 \pm 0.06^{\mathrm{b}}$ \\
\hline Girth $(\mathrm{cm})$ & $7.82 \pm 0.13^{\mathrm{a}}$ & $7.65 \pm 0.11^{\mathrm{a}}$ & $7.17 \pm 0.18^{\mathrm{b}}$ & $6.95 \pm 0.13^{\mathrm{b}}$ \\
\hline
\end{tabular}

a,b,c Data figures with different superscript letters across the rows are significantly different from each other at $\mathrm{P}<0.05$

${ }^{1} \mathrm{Feeding}$ frequency is once per day

${ }^{2}$ Feeding frequency is twice per day

${ }^{3}$ Feeding frequency is thrice per day

${ }^{4}$ Feeding frequency is four times per day

Table 2:Growth and length of goldfish at the start of feeding trial.

\begin{tabular}{|c|c|c|}
\hline Feed & Weight Gain $(\mathrm{g})^{1}$ & FCR $(\mathrm{g}: \mathrm{g})$ \\
\hline A & $64.95 \pm 0.06^{\mathrm{a}}$ & $1.28 \pm 0.04^{\mathrm{a}}$ \\
\hline B & $68.47 \pm 0.04^{\mathrm{b}}$ & $2.63 \pm 0.02^{\mathrm{b}}$ \\
\hline C & $58.47 \pm 0.09^{\mathrm{c}}$ & $3.94 \pm 0.06^{\mathrm{c}}$ \\
\hline D & $29.02 \pm 1.00^{\mathrm{d}}$ & $9.66 \pm 0.03^{\mathrm{d}}$ \\
\hline
\end{tabular}

a,b,c,d Data figures with different superscript letters across the rows are significantly different from each other at $\mathrm{P}<0.05$

${ }^{1}$ Weight gain was calculated by dividing average weight of 10 fish minus the initial weight

${ }^{1}$ Feed A means feeding frequency is once per day

${ }^{2}$ Feed $\mathrm{B}$ means the feeding frequency is twice per day

${ }^{3}$ Feed $\mathrm{C}$ means the feeding frequency is thrice per day

${ }^{4}$ Feed $D$ means the feeding frequency is four times per day

Table 3: Weight gain and FCR of goldfish reared under various feeding frequency regimes 
Citation: Hafeez-ur-Rehman M, Iqbal KJ, Abbas F, Mushtaq MMH, Rasool F, et al. (2015) Influence of Feeding Frequency on Growth performance and Body Indices of Goldfish (Carrassius auratus). J Aquac Res Development 6: 336. doi:10.4172/2155-9546.1000336

Page 3 of 4

\begin{tabular}{|c|c|c|c|c|c|c|c|c|}
\hline Correlation & Weight & Length & Caudal Fin & Girth & pH & Temp. & DO & Salinity \\
\hline Weight & NS & NS & NS & NS & NS & NS & NS & NS \\
\hline Length & NS & NS & NS & NS & NS & NS & NS & NS \\
\hline Caudal Fin & $0.548^{* *}$ & $-0.792^{* * *}$ & NS & NS & NS & NS & NS & NS \\
\hline Girth & NS & NS & NS & NS & NS & NS & NS & NS \\
\hline $\mathrm{pH}$ & NS & NS & NS & NS & NS & NS & NS & NS \\
\hline Temp & NS & NS & NS & NS & NS & $0.729^{\star * *}$ & NS & NS \\
\hline Do & NS & NS & NS & NS & NS & $0.538^{*}$ & NS & NS \\
\hline Salinity & NS & NS & NS & NS & NS & NS & NS & NS \\
\hline
\end{tabular}

NS- Non-significant; * $\mathrm{P}<0.05 ;{ }^{* *} \mathrm{P}<0.010 ;{ }^{* * *} \mathrm{P}<0.001$

Table 4: Pearson Correlation between weight, length, caudal fin, girth, $\mathrm{pH}$, temperature, dissolved oxygen, and salinity

(once, thrice, once and twice a day). James and Sampath [26] had similar findings in Siamese fighting fish (Bettas plendens. Regan) who showed that fish fed twice a day to satiation elicited maximum growth and reproductive output when compared with its counterparts (1 meal in $3 \mathrm{~d}, 1 \mathrm{meal}$ in $2 \mathrm{~d}, 1 \mathrm{meal} / \mathrm{d}$, and 3 meals/d). Contrary to our results commercially cultured fish species such as Black Rockfish (Sebastes schlegeli) suggested that feeding to satiation once a day resulted in optimum growth [27]. Gibel Carp (Carrassius auratus gibelio), showed a significant surge in growth rate and feed efficiency when feeding frequency increased from 2 to $3,4,12$, and 24 feedings per day, with the recommendation of 24 feeding times per day for this species [15]. The difference in results might be due to the fact that goldfish is not usually reared for commercial purpose. Moreover, this fact also leads to the fact that there is a need to improve the genetic potential of goldfish if we want to rear it for commercial reasons. In the present study, the maximum weight gain was observed in the feed (B) and the same result was observed in Siamese fighting fish (Betta splendens. Regan) which showed that 2 meals per day fed to satiation are sufficient to support the maximum growth. Further it has been reported that ornamental Red Swordtail (Xiphophorus helleri) fed 2 meals per day resulted in the greatest growth [28]. But contrary to present study the juvenile Atlantic Halibut (Hippoglossus hippoglossus) displayed improved growth rates when fed on satiation 5 times per day, compared with one time per day [29], and African Catfish (Clarias gariepinus) exhibited greater growth rates when fed to satiation twice compared with 3 times per day [30]. In the present study the better feed conversion ratio (FCR) was observed in Feed (A) but contrary to present study best FCR were observed for the Goldfish fed 4 times per day, indicating that this frequency of feeding was optimal, suggesting that both growth and feed utilization are more efficient at this feeding frequency [31].

\section{Conclusion}

It is inferred that frequency feeding has profound effects on growth of goldfish. However two times per day feeding frequency is better choice for maximum body weight gain but the efficiency of feed could be improved if feed frequency remained once per day. Moreover, for rearing goldfish at commercial level it is recommended to geneticist and breeders to improve its genetic potential.

\section{References}

1. Lim LC, Wong CC (1997) Use of the rotifer, Brachionus calyciflorus Pallas, in freshwater ornamental fish larviculture. Hydrobiologia 358: 269- 273.

2. Mandal B, Mukherjee A, Banerjee S (2010) Growth and pigmentation development efficiencies in fantail guppy, Poecilia reticulate fed with commercially available feeds. Agriculture and Biology Journal of North America 1: 1264-1267.

3. Lee JS, Newman ME (1997) Aquaculture Business. Interstate Publishers Inc USA.
4. NRE (Natural Resources and Environment, Victoria, Australia). 2002. Commercial Fish Production Information Bulletin 2002. Marine and Freshwater Resources Institute, Melbourne, Australia.

5. Sampath K, Pandian TJ (1984) Interactions of feeding frequency and density on feed utilization in air-breathing murrel, Channa striatus. Proceedings of Indian Academy of Scineces 93: 445-453

6. James R, Muthukrishnan J, Sampath K (1993) Effect of food quality on tempora and energetics cost of feeding in Cyprinuscarpio (Cyprinidae). J Aquac Trop 8: 47-53.

7. Jobling $M$ (1998) Feeding and nutrition in intensive fish farming. Sheffield Academic Press, USA

8. Andrews JW, Pages JW (1975) The effects of frequency of feeding on culture of catfish. Transactions of the American Fisheries Society 104: 317-321.

9. Chua TW, Teng S (1978) Effects of feeding frequency on the growth of young estuary grouper Epinephelus tauvina (Forskal) cultured in floating net cages. Aquaculture 14: 31-47

10. Marian MP, Ponniah AG, Pitchairaj R, Narayanan M (1982) Effect of feeding frequency on surfacing activity and growth in air breathing fish, Heteropneustes fossilis. Aquaculture 26: 237-244.

11. Sampath K (1984) Preliminary report on the effects of feeding frequency in Channa striatus. Aquaculture. 40: 301-306.

12. Jobling $M$ (1983) Effect of feeding frequency on food intake and growth of Arctic charr, Salvelinus alpinus L. Journal of Fish Biology. 23: 177-185.

13. Sampath K, Ravindran J (1988) Optimum meal frequency in the fry of Cirrhinus mrigala (Hamilton). Proceedings of 1st Indian Fisheries Forum Asian Fisheries Society.

14. Wang N, Hayward RS, Noltie DB (1998) Effect of feeding frequency on food consumption, growth, size variation, and feeding pattern of age-0 hybrid sunfish. Aquaculture 165: 261-267.

15. Zhou Z, Cui Y, Xie S, Zhu X, Lei W, et al. (2003) Effect of feeding frequency on growth, feed utilization, and size variation of juvenile gibel carp (Carrassius auratus gibelio). Journal of Applied Ichthyology 19: 244-249.

16. Degani G, Gur N (1992) Growth of juvenile Tricogaster leerii (Bleeker, 1952) on diets with various protein levels. Aquaculture and Fishery Management 23 161-166.

17. Degani G (1993) Growth and body composition of juvenile Pterophyllum scalare (Lichtonstein) (Pisces:Cichlidae) at different densities and diets. Aquaculture and Fishery Management 24: 725-730.

18. Degani G, Yehuda V (1996) Effects of diets on reproduction of angelfish Pterophyllum scalare (Cichlidae). Indian Journal of Fisheries 43: 121-126.

19. Boyd CE (1998) Water quality for pond aquaculture. Res and Develop Series 43: 1-11.

20. Environmental Review (ER) (2008) Coastal Zone Aquaculture Management. Aquaculture Strategic Plan 5: 1-14.

21. Meade JW (1989) Aquaculture Management. Van Nostrand Reinhold Publishers New York.

22. Brian O (2006) Dissolved Oxygen Environmental quality.

23. Ita EO, Balogun JK, Adimula AB (1995) A preliminary report of preimpoundment of fishes Survey of Goronyo Reservoir Sokoto. NIFFR Annual Report. 
Citation: Hafeez-ur-Rehman M, Iqbal KJ, Abbas F, Mushtaq MMH, Rasool F, et al. (2015) Influence of Feeding Frequency on Growth performance and Body Indices of Goldfish (Carrassius auratus). J Aquac Res Development 6: 336. doi:10.4172/2155-9546.1000336

24. McElwee K, Lewis K, Nidiffer M, Buitrago P (2002) Nineteenth Ann. Tech. Rep. Pond Dynamics/Aquaculture CRSP, Oregon State Univ., Corvallis, Oregon, Studies on potential use of salinity to increase growth of Tilapia in Aquaculture in Malawi.

25. Watanabe WO, French KE, Ernst DH, Olla BL, Wicklund RI (2007) Salinity during early development influences growth and survival of Florida red tilapia in brackish and seawater. J. World Aqua Soc 20: 134-142.

26. James R, Sampath K (2003) Effect of meal frequency on growth and reproduction in the ornamental red swordtail (Xiphophorus helleri). Israeli Journal of Aquaculture-Bamidgeh 55: 197-207.

27. Guen-Up K, Jo-Young S, Sang-Min L (2004) Effects of feeding frequency and dietary composition on growth and body composition of juvenile rockfish (Sebastes schlegeli). Faculty of Marine Biosience and Technology, Kangnung National University Gangneung.
28. James R, Sampath K (2004) Effect of feeding frequency and fecundity in an ornamental fish, Betta splendens (Regan). Israeli Journal of AquacultureBamidgeh. 56:138-147.

29. Schnaittacher G, King W, Berlinsky DL (2005) The effects of feeding frequency on growth of juvenile Atlantic halibut, Hippoglossus hippoglossus L. Aquaculture Research 36: 370-377.

30. Pantazis PA, Neofitou CN (2003) Feeding frequency and intake in the African catfish Clariasgariepinus (Burchell 1822). Israeli Journal of AquacultureBamidgeh 55: 160-16

31. Priestley SM, Stevenson AE, Alexander LG (2006) The Influence of Feeding Frequency on Growth and Body Condition of the Common Goldfish (Carrassius auratus) American Society for Nutrition. Journal of Nutrition 136: 1979S-1981S. 